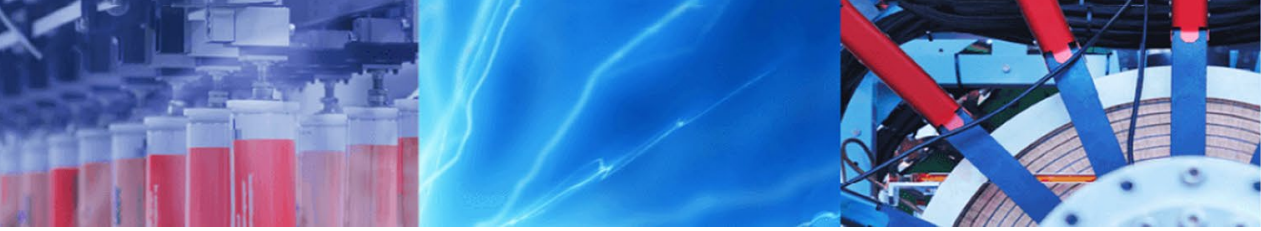

Research Article

\title{
Description and effective parameters determination of the production process of fine-grained artificial stone from waste silica
}

\author{
Zahra Bagherpor $^{1} \cdot$ Sabereh Nazari $^{2} \cdot$ Parisa Bagherzadeh $^{3} \cdot$ Ali Fazlavi $^{1}$
}

(c) Springer Nature Switzerland AG 2019

\begin{abstract}
In this study, waste silica from Alborz silica mineral processing factory was recycled as raw material for the production of a novel artificial stone to be used in civil construction. The size of the waste materials of this plant is less than 100 microns. Waste silica powder was mixed with unsaturated polymer resins as a binder. Under pressure, vibration and vacuum conditions, artificial stone with high compressive strength of $100 \mathrm{MPa}$, the tensile strength of $37 \mathrm{MPa}$ and flexural strength of $98 \mathrm{MPa}$ was produced within $15 \mathrm{~min}$. Furthermore, in all of the produced artificial stones, due to the usage of resin, the flexural strength is higher than the tensile strength whereas, in natural stones, tensile strength is more than flexural strength. Moreover, using bentonite made a positive effect on the strength and quality of the stone, whereas kaolin declined the quality and the resistance of the artificial stone. Besides, the produced artificial stone has a lower specific gravity $\left(2.14 \mathrm{~g} / \mathrm{cm}^{3}\right)$ and water absorption $(0.06 \mathrm{~g})$ than natural stone, which is one of the most prominent advantages of artificial stone. What's more, low corrosion and were obtained against diluted sulfuric acid $(0.0097 \mathrm{~g})$ and hydrochloric acid $(0.0313 \mathrm{~g})$. Besides, due to the presence of impurities in the waste materials of Alborz silica factory, the produced artificial stones are brown. To reach the desired color, there are several metal oxides which could be added to the combination.
\end{abstract}

Keywords Waste silica $\cdot$ Artificial stone $\cdot$ Resin $\cdot$ Effective parameters

\section{Introduction}

Residues generated from all industrial sectors such as industrial ashes and plastic wastes as well as particle residues are currently considered as an environmental problem. Mining and mineral processing operations provide raw materials needed for life. It is inevitable to produce environmental pollutions during such operations, since a great amount of material are left useless as waste. Nowadays, inappropriate disposal of mentioned residues is a worldwide problem. Therefore, finding a way to use such materials to produce useful supplies has great effect in environment protection [1-8].
Silica particles are generated in glass production process, such as grinding, cutting, crushing and sieving operations. Thousands of tons waste silica are produced in mineral processing plants annually, which is a considerable amount. Such impurities are usually discarded in the nature and lead to several environmental hazards, due to the fact that the mentioned residual particles cannot return to the cycle of the nature even in long-term [9-13]. The effects of fine residual particles of silica factories on air quality were briefly addressed in environmental impacts. Also, these particles scratch delicate tissues in respiratory system, causing damage that impairs breathe ability and oxygen delivery to blood stream [14].

\footnotetext{
$\triangle$ Sabereh Nazari, saharnazari2626@gmail.com | ${ }^{1}$ Department of Mining Engineering, Imam Khomeini International University, Qazvin, Iran. ${ }^{2}$ School of Resources Engineering, Xi'an University of Architecture and Technology, Xi'an 710055, China. ${ }^{3}$ Department of Mining Engineering, Tarbiat Modares University, Tehran, Iran.
} 
In Iran, fine and coarse silica particles are generated in huge amounts through the country. Glass industry generates thousands of tons residues per year which are disposed in huge landfills. Moreover, Qazvin which has numerous quarries made considerable amount of residues, about of 50,000 tons a year.

Indeed, numerous research works have been allocated to find scientific solutions for declining the environmental troubles of residues. For example, waste materials which have been applied for asphalt concrete pavement fabrication were mixed with cement concrete. Also these waste materials were used in production process of low strength materials, lightweight aggregates and construction materials such as red bricks [2, 15-20].

One of the useful solutions for reducing waste mining material hazards is artificial stones production. Artificial stones are compounds made up of crushed pieces of natural stones and resins [21-25]. Several researches have studied the process of artificial stone production. In Lee and Ko [23] studies, waste glass and stone fragments from stone slab processing were recycled as raw materials to make artificial stone slabs using vibratory compaction in a vacuum environment. The study was based on compaction pressure, vacuum condition, and vibration frequency. The results indicate that artificial stone slabs were made with high compressive strength of $148.8 \mathrm{MPa}$ and flexural strength of $51.1 \mathrm{MPa}$. In a study conducted by Cruz [22], the process was provided for manufacturing outdoor artificial stone boards by methacrylate resin using vibrocompression under vacuum system. In this research, liquid methacrylate resin with $200-2000$ centipoises viscosity and $90-99 \%$ content has mixed with methacrylate resin in $1-10 \%$ content and lower than 200 centipoises viscosities which result in high quality artificial stone. In the study of Chang et al. [21], waste stone sludge obtained from slab stone processing and waste silt from aggregate washing plants were recycled to manufacture artificial aggregate. The result showed that by mixing fine-powdered stone sludge with waste silt of larger particle size and applying vibratory compaction, the compressive strength was obtained to above 29.4 MPa. A new technique on mechanical behavior of artificial and natural stones has developed by Dos Santos et al. [26] based on young's modulus (E) and temperature from 20 to $200^{\circ} \mathrm{C}$. The results indicate that young's modulus (E) of each materials determined at ambient temperature, and the engineered stones keep almost the same value of $E$ after thermal ageing or thermal shock up to $160^{\circ} \mathrm{C}$. An investigation was carried out by Souza Silvaa et al. [27] for evaluating the mechanical and physical properties of produced artificial marble based on calcite marble waste and epoxy resin. The results indicated that the artificial stones exhibit a maximum flexural strength of $31.8 \mathrm{MPa}$, maximum compressive strength of $85.2 \mathrm{MPa}$ and water absorption below $0.05 \%$. The effects of alkali dosage, slag content and curing age on compressive strength of artificial flood-prevention stone have been evaluated by Wang et al. [28]. The results showed that the specimen made from optimal mix proportion can meet the requirement of flood-prevention stone and the main product in alkali-activated process is $\mathrm{C}-\mathrm{S}-\mathrm{H}$ gel. In a research conducted by Peng and Qin [29], the mechanical behavior and microstructure of artificial stone was studied. Based on their results, artificial stone slabs obtained in this work has high compressive and flexural strengths of 170.9 and $73.5 \mathrm{MPa}$ under a compaction time of $3 \mathrm{~min}$ and a curing time of $60 \mathrm{~min}$.

As a matter of fact, the practical possibility of using artificial stone instead of natural one is based on the technical advantages, such as the lower density of the polymeric resin $\left(\sim 1 \mathrm{~g} / \mathrm{cm}^{3}\right)$ in comparison with the natural stone $\left(\sim 2 \mathrm{~g} / \mathrm{cm}^{3}\right)$, which makes the artificial stone significantly lighter. Another advantage of artificial stones is lower amount of pores and flaws. Whereas, high porosity and microstructural defects in natural ornamental stones lead to contamination and brittleness, since outside fluids can penetrate to natural stone through pores and propagate cracks. Despite abovementioned positive points of artificial stones, it should be noted that some of them are not resistant enough in high traffic areas, as the materials are vulnerable to abrasion [11, 30, 31].

This work is an investigation on the production of artificial stone by waste silica from residue industrial materials. As a novelty, it is the first time that the size of the residues is less than 100 microns and silica has got impurities. These impurities are difficult to separate from waste materials whereas they are fruitful to increase artificial stone strength. As these impurities cause several environmental problems in the region, this is an appropriate way to abolish them. The main objective of this work is to produce a novel product using process techniques of vibration, vacuum and pressing, which has superior mechanical and physical properties as well as resistance to chemical reactions. Therefore, the production of artificial stone using impure silica declines environmental pollution and also economizes the production process in civil construction applications.

\section{Methodology}

\subsection{Materials}

A representative sample of waste silica from Alborz silica factory (Qazvin, Iran) with the size of $-100 \mu \mathrm{m}$ was used for experiments. Table 1 shows the XRF analysis of the sample. 
Table 1 XRF analysis of the waste materials of Alborz silica factory

\begin{tabular}{lllllllll}
\hline $\begin{array}{l}\text { Type of elements } \\
\text { (\%) }\end{array}$ & $\mathrm{SiO}_{2}$ & $\mathrm{Al}_{2} \mathrm{O}_{3}$ & $\mathrm{Fe}_{2} \mathrm{O}_{3}$ & $\mathrm{CaO}$ & $\mathrm{MgO}$ & $\mathrm{K}_{2} \mathrm{O}$ & $\mathrm{Na}_{2} \mathrm{O}$ & $\mathrm{LOI}$ \\
& 96.31 & 1.6 & 0.185 & 0.3 & 0.2 & 0.65 & 0.1 & 0.65 \\
\hline
\end{tabular}

Notably, waste materials of the factory contain large amount of silica (96\%). Other impurities such as $\mathrm{Al}_{2} \mathrm{O}_{3}$, $\mathrm{Fe}_{2} \mathrm{O}_{3}$ and etc. have positive effect on artificial stone strength and quality.

Also, a high purity silica sample (purity over $99.9 \%$ ) with size of -100 micron were used to consider the effect of super pure silica on produced artificial stone. Moreover, orthophthalic unsaturated polymer resins were used as a binder. Figure 1 show the structure of orthophthalic unsaturated resin. Sulfuric acid and hydrochloric acid with $10 \%$ concentration were used in this experiment. Cobalt (1-2\%) and Methyl Ethyl Ketone Peroxide (2\%) were also added to the resin as resin hardeners. Bentonite and kaolinite (Lushan mine in Iran) were used to evaluate the quality of artificial stone. After finding best powder-resin ratio, bentonite and kaolin were used to consider which better filler is.

\subsection{Method}

First, waste materials were sieved and fine particles smaller than 100 microns used for experiments. Then, orthophthalic unsaturated polymer resins added as a binder. For primary tests, 3 distinct mixtures with different powderresin ratio have tested.

1. The content ratio of $70 \%$ powder to $30 \%$ resin.

2. The content ratio of $80 \%$ powder to $20 \%$ resin.

3. The content ratio of $85 \%$ powder to $15 \%$ resin.

The mixture is mixed to obtain homogeneous material. Incomplete mixing of materials and resins makes inhomogeneous mixture. Moreover, a complete mixing accelerates polymerization reaction and accordingly increases the strength of artificial stone. It should be noted that, mixing time is extremely crucial since resin is hardened in short period of time. Therefore, production process should be done very quickly. After finding best powder to resin ratio, bentonite and kaolin ( $3 \%-3 \mathrm{~min}$ ) were used to investigate which filler is better. Then, vibration press machine used in vacuum condition. The mixture is placed in a steel vessel and allowed to vibrate in $50 \mathrm{~Hz}$ for $3 \mathrm{~min}$. In this machine, obtained paste became completely homogeneous, and air inside particles has released. After vibration stage, material has immediately pressed by 3 tons in 4 min until the block of artificial stone got the mold shape. In fact, Operation time for mixing, vibration and pressure should be less than $15 \mathrm{~min}$, since resin is hardened within $15 \mathrm{~min}$. In next stage, the block is heated at temperature of $90^{\circ} \mathrm{C}$ for $55 \mathrm{~min}$ to complete polymerization process of resin to reach final strength of the artificial stone as well as releasing moisture. Then, blocks has kept in a desiccator jar to return room temperature, around $22^{\circ} \mathrm{C}$.

Criterion of determining best composition is maximum compressive and flexural strength. In this regard, compressive, tensile and flexural strength experiments have been done based on ASTM C39, ASTM C496 and ASTM C78 standards, respectively. Specific gravity is the ratio of the weight of a given volume of materials, including permeable and impermeable voids in the particles, to the weight of an equal volume of water. The specific gravity and water absorption of the novel artificial stone were measured according to ASTM C642 standard. The resistance to chemical attack has conducted according to the Brazilian NBR 15845 standard. After being subjected to the chemical attack for $24 \mathrm{~h}$ of specific reagents, the specimens had corresponding weight loss determined. Moreover, the pore size has studied from the desorption branch of the isotherm using DFT method (Quanta chrome Instruments, 1994-2006).

Fig. 1 Molecular structure of orthophthalic unsaturated resin

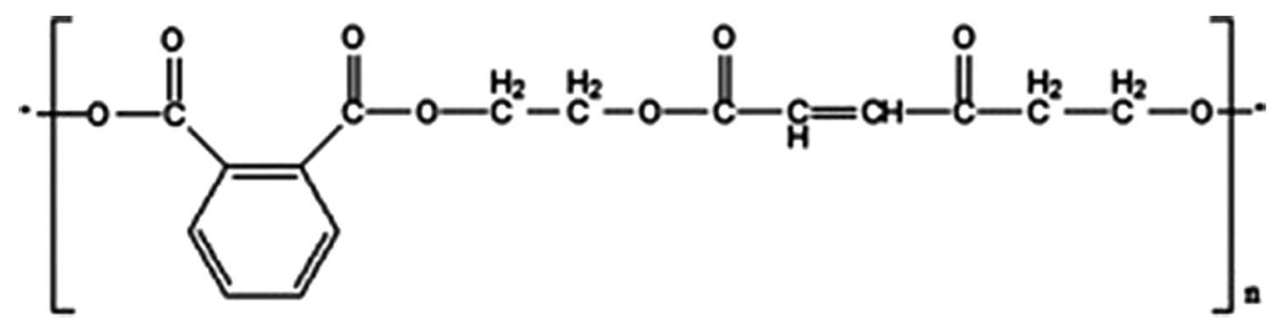




\section{Results and discussion}

\subsection{Effective factors in artificial stone production}

\subsubsection{Effect of powder to resin ratio}

One of the most important factors in production process of artificial stone is powder-resin ratio. For testing different compositions, the content ratio of powder was increased from 70 to $85 \%$. Table 2 and Fig. 2 show the average compressive, tensile and flexural strength of artificial stone in 10 samples with powder/resin ratios of $70 / 30,80 / 20$ and $85 / 15$ in same experimental condition.
The results show that maximum compressive, tensile and flexural strength were obtained in 80/20 powder/resin ratio. Figure 3 shows manufactured artificial stone with a powder/resin ratio of $80 / 20$ and $85 / 15$. According to Figs. 2 and 3, artificial stone with powder/resin ratio of $80 / 20$ has maximum strength, because of lower porosity in this ratio, also increasing powder amount (over 80\%) makes brittle compound which may burst in loading operation. Pore size distributions in different powder/ resin ratio (70/30, 80/20 and 85/15) are shown in Fig. 4. Pores diameter is between 3-15 and 3-10 microns in $70 / 30$ and $85 / 15$ powder/cement ratio respectively. Pore size has decreased to $3-8$ microns in $80 / 20$ ratio. So pore
Table 2 Compressive, tensile and flexural strength for 10 sample

\begin{tabular}{lrll}
\hline Powder/resin ratio & $\begin{array}{l}\text { Compressive strength } \\
(\mathrm{MPa})\end{array}$ & Tensile strength (MPa) & Flexural strength (MPa) \\
\hline $70 / 30$ & $24.51 \pm 0.01$ & $15.14 \pm 0.01$ & $35.11 \pm 0.01$ \\
$80 / 20$ & $100.15 \pm 0.01$ & $37.33 \pm 0.01$ & $98.33 \pm 0.01$ \\
$85 / 15$ & $40.45 \pm 0.01$ & $24.42 \pm 0.01$ & $55.54 \pm 0.01$ \\
\hline
\end{tabular}

Fig. 3 Artificial stone produced with powder/resin ratio: a $80 / 20$, b $85 / 15$
Fig. 2 Effect of powder/ resin ratio on artificial stone strength
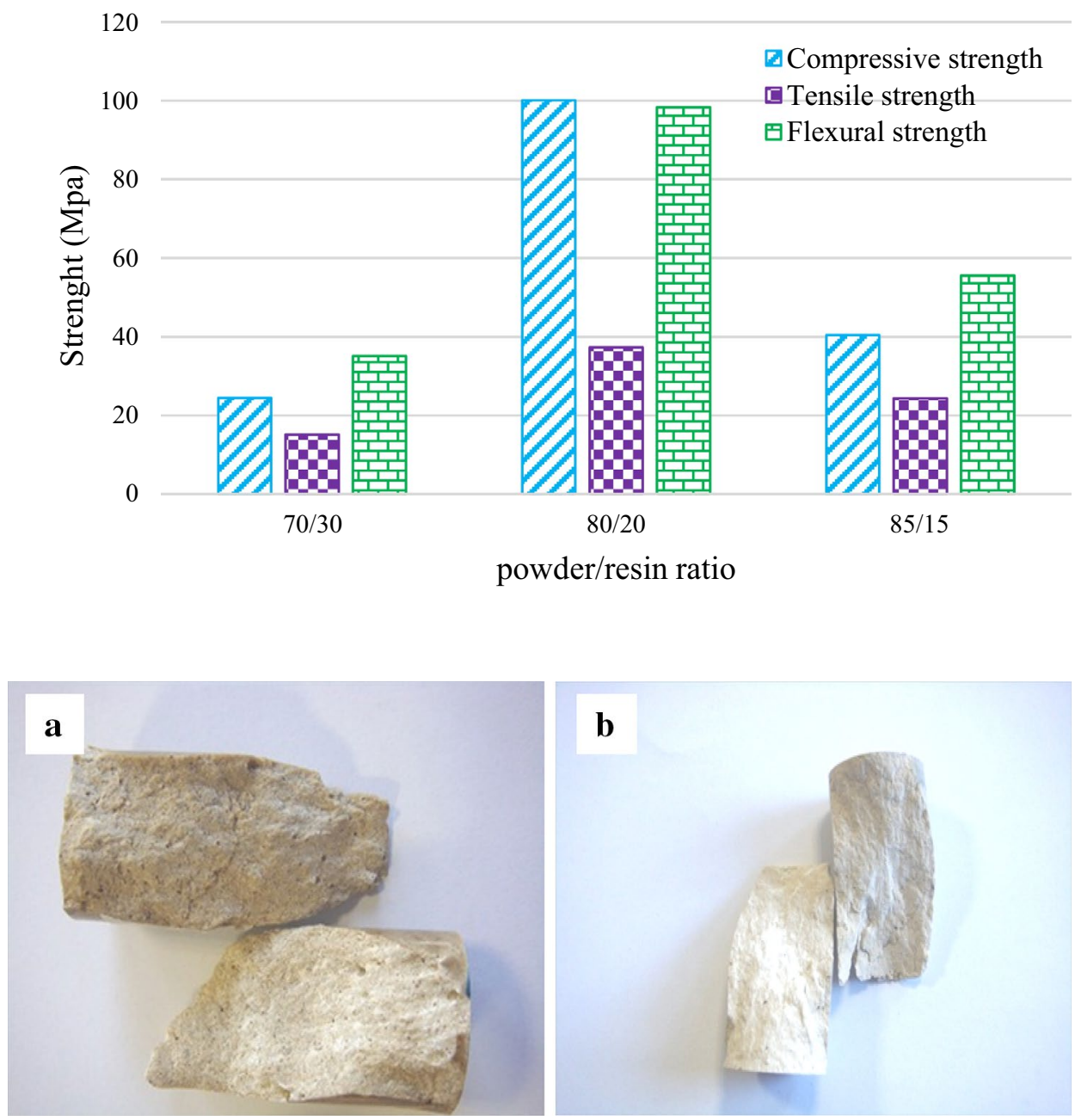
Fig. 4 DFT pore-size distributions of samples with ratio of $70 / 30,80 / 20$ and $85 / 15$

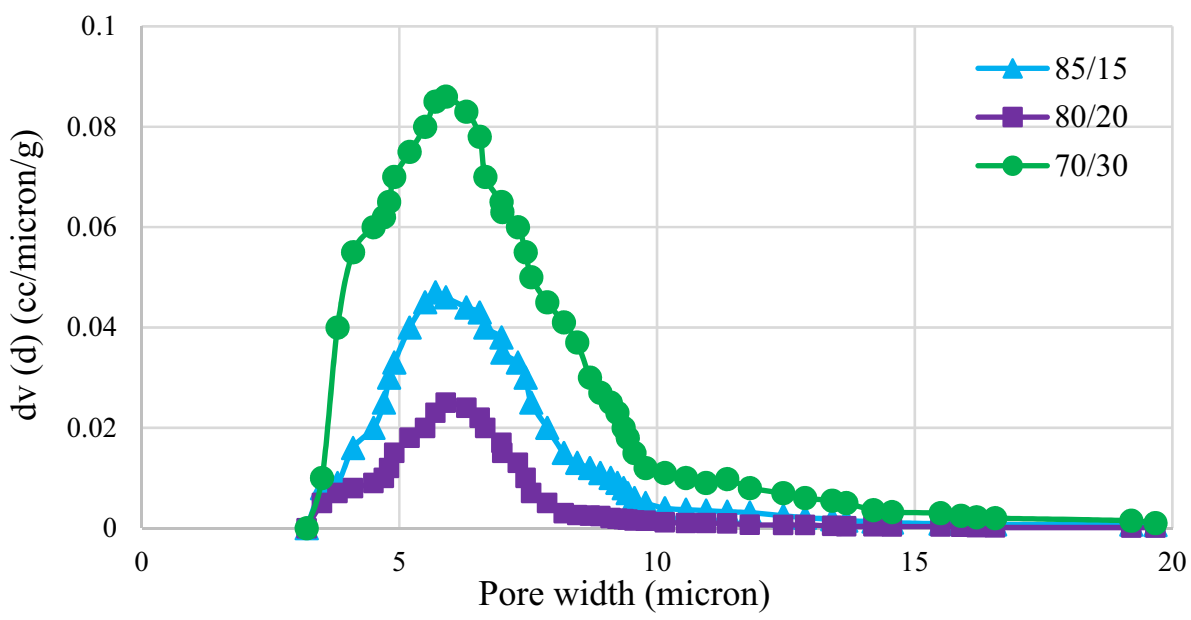

size distribution has got broader in more and less ratio of $80 / 20$.

\subsubsection{Amount and type of additives}

3.1.2.1 Resin additives Resin additives or resin hardeners include cobalt and methyl ethyl ketone peroxide. The process of hardening and polymerization cannot be done without these materials. These additives and resin are complementary and they are not added to the resin before its consumption to prevent early hardening. The process of mixing resins and hardeners should be done very well to reach a homogenous mixture because it spreads hardener particles throughout the mixture and consequently, polymerization would accelerate. In above mentioned conditions artificial stone would reach higher resistance. If resin does not mix well with hardeners, the mixture will not be homogeneous, the reaction between resin and hardener will not be done well and the hardening procedure will perform very slowly or not at all.

3.1.2.2 Mineral additive to waste materials Some minerals such as kaolin and bentonite were used to increase artificial stone quality. Table 3 indicates the average resistances of artificial stones with different compositions in 10 samples.

Figure 5 shows the difference between compressive strength, flexural strength and tensile strength of artificial stones with different compounds. As is seen, higher compressive strength is obtained in $80 / 20$ powder/resin ratios, using $3 \%$ bentonite and $50 \mathrm{~Hz}$ vibration. After vibratory compaction, artificial aggregate packing improved and reached a more compacted structure with higher compressive strength. It seems that compressive strengths, regardless of groups, tended to increase with $3 \%$ bentonite; while it descended by pure silica. Pure silica does not have positive effect and decrease artificial stone strength. Figure 6 shows artificial stones containing kaolin and bentonite. Applying bentonite makes positive effect on stone quality, while kaolin has opposite result. Bentonite component significantly affects properties of artificial stone, and hence is of importance in construction engineering. Important properties of bentonite include water absorption and swelling, viscosity and thixotropy of aqueous suspensions, colloidal and waterproofing properties, binding and surface properties (properties and uses of Bentonite, [32]). Thus, bentonite increases compressive, tensile and flexural strength of stone without affecting the color and other characteristics of artificial stone. On the other hand, kaolinite does not have positive effect on artificial stone's properties. The reason is kaolin's properties such as soft consistency and earthy texture. Also, it is easily broken and can be molded or shaped, especially when wet [33].

In whole produced artificial stones, because of resin and plastic properties, flexural strength is higher than tensile strength whilst natural stones do not resistant
Table 3 The average resistance of artificial stone with different compounds under vibration of $50 \mathrm{~Hz}$ for 10 samples

\begin{tabular}{lrcc}
\hline Type of stone & $\begin{array}{l}\text { Compressive } \\
\text { strength (MPa) }\end{array}$ & Tensile strength (MPa) & Flexural strength (MPa) \\
\hline Artificial stone with pure silica & $40.15 \pm 0.01$ & $15.19 \pm 0.01$ & $20.94 \pm 0.01$ \\
Artificial stone without purification & $100.52 \pm 0.01$ & $34.33 \pm 0.01$ & $95.37 \pm 0.01$ \\
Artificial stone with 3\% kaolin & $32.52 \pm 0.01$ & $22.13 \pm 0.01$ & $85.42 \pm 0.01$ \\
Artificial stone with 3\% bentonite & $110.12 \pm 0.01$ & $41.35 \pm 0.01$ & $105.72 \pm 0.01$ \\
\hline
\end{tabular}


Fig. 5 Difference between compressive, flexural and tensile strength of artificial stones
Fig. 6 Artificial stones produced with: a kaolin, b bentonite

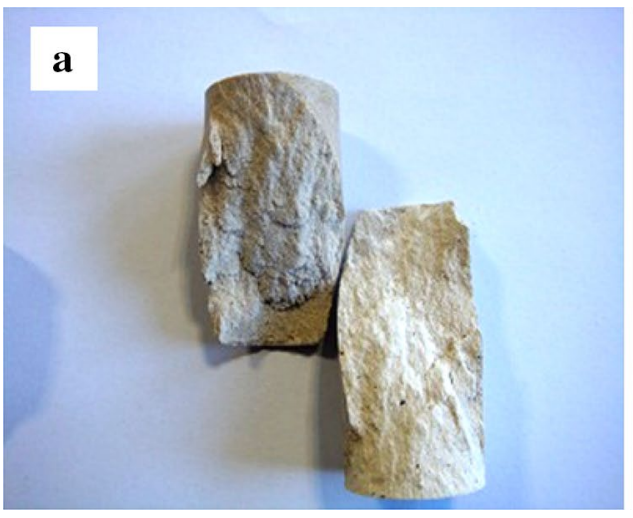

b

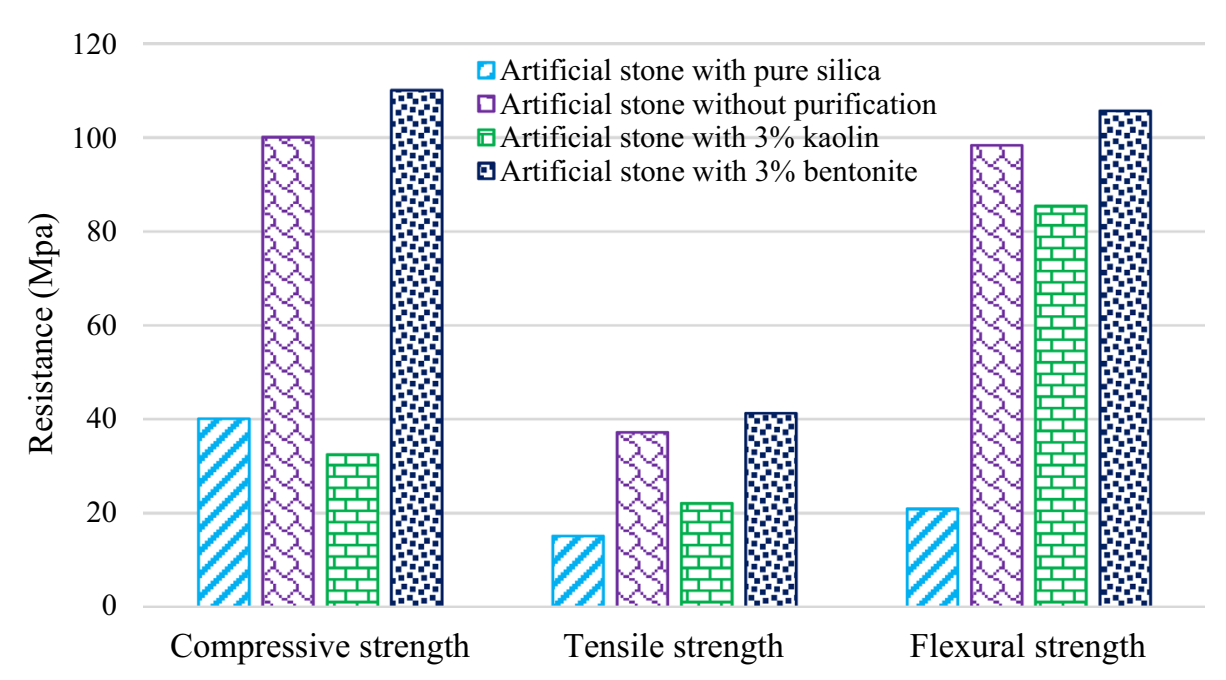

produces low amount of tailings and this is one of the most important results achieved in this research.

\subsubsection{Effect of temperature}

It is generally agreed that temperature is crucial factor in mechanical properties of artificial stone. Figure 7 shows compressive, tensile and flexural strength of artificial stone with $3 \%$ bentonite at different temperatures. Maximum compressive strength $(110 \mathrm{MPa})$ has obtained at $90^{\circ} \mathrm{C}$. This parameter has decreased slightly in more and less temperatures. At temperatures more than $90^{\circ} \mathrm{C}$, the stone is baked more that reduces compressive strength below $50 \mathrm{MPa}$. At temperatures lower than $90^{\circ} \mathrm{C}$, setting process would not be done well which decrease stone quality. Figure 8 shows produced artificial stones at $130^{\circ} \mathrm{C}$ with compressive strength of $45 \mathrm{MPa}$. It is perceived that artificial stones behave more like an elastic-plastic material in comparison to more brittle/elastic behavior of natural stones. By increasing temperature, the polymer-resin matrix starts contributing with its rheological behavior to mechanical properties of composites. 
Fig. 7 Effect of temperature on various artificial stone resistances

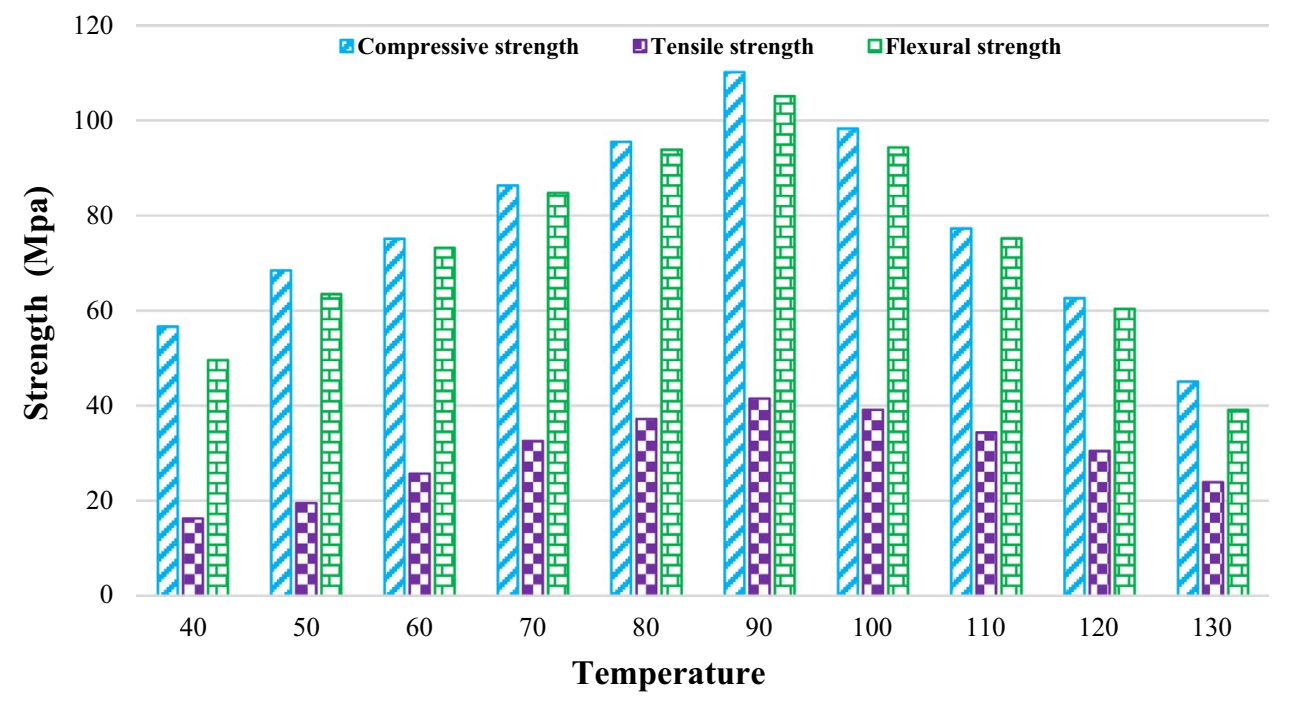

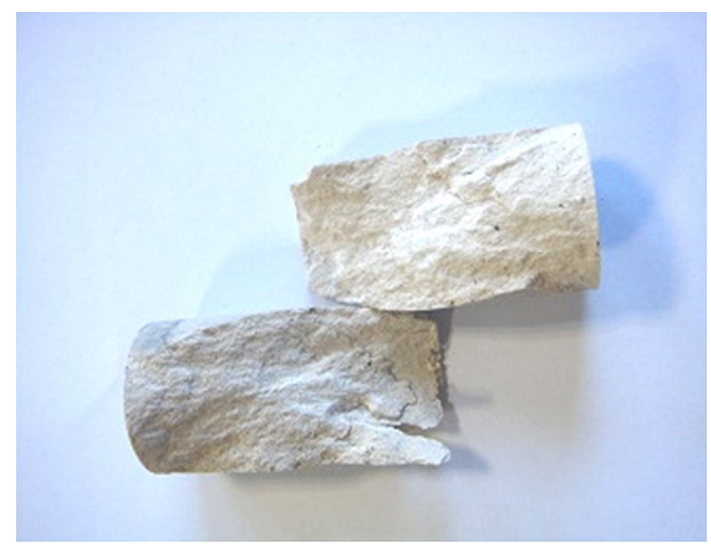

Fig. 8 Artificial stone produced at $130^{\circ} \mathrm{C}$

Table 4 Specific gravity, water absorption and porosity

Specific gravity $\left(\mathrm{g} / \mathrm{cm}^{3}\right)$

$2.14 \pm 0.02$

Water absorption (\%)

$0.06 \pm 0.03$

Porosity (\%)

$0.12 \pm 0.04$

\subsubsection{Effect of stone physical properties}

Table 4 shows specific gravity, porosity and water absorption values. It is observed that produced artificial stone has lower specific gravity, which is one of the most prominent advantages of artificial stones properties. Specific gravity of natural granite is $2.7 \mathrm{~g} / \mathrm{cm}^{3}$ that is almost $30 \%$ heavier than artificial stones, while specific gravity of artificial stone in present study is $2.14 \mathrm{~g} /$ $\mathrm{cm}^{3}$. Binder used in this study is an unsaturated polymer resin which has viscous behavior. On the other hand, once the structure compacted, the air trapped between aggregates during mixing cannot be easily removed. Air can only be eliminated when compaction is conducted in a vacuum condition. Removing air leads to a lower porosity in production process of artificial stone. So, there are fewer discernible pores in densified structure formed under the vibration of $50 \mathrm{~Hz}$ which has compressive strength of $110.12 \mathrm{MPa}$.

According to Table 4 water absorption of $0.06 \%$ gained by this method is significantly lower than other methods. High water absorption of $0.25 \%$ and $0.38 \%$ reported by Borselino et al. and Carvalho et al., respectively. One of the reason is that the porosity of this method is lower than other methods [34, 35]. A possible explanation is that this artificial stone can be sealed with low water absorption.

\subsection{Artificial stone color}

The produced artificial stone is brown due to the presence of impurities in waste powders of Alborz silica factory. For various colors, it is necessary to add various metal oxides such as titanium oxide, chromium oxide, copper oxide, zirconium oxide and so on. Figure 9 shows the artificial stones with $3 \%$ titanium oxide content with white color. Metal oxides are used up to 3 wt $\%$ depending on the quality of silica powder in mixture. Table 5 shows the effect of metal oxides on artificial stone strength. Based on conducted experiment, using metal oxides does not make a significant impact on strength of artificial stone. So, they can be used for dying the stone for specific usage. It is interesting that titanium oxide gives white color, combination of titanium oxide and copper oxide makes the artificial stone red and zirconium oxide is a great agent for giving cream color to artificial stone. 
Fig. 9 Artificial stones with 3\% titanium oxide

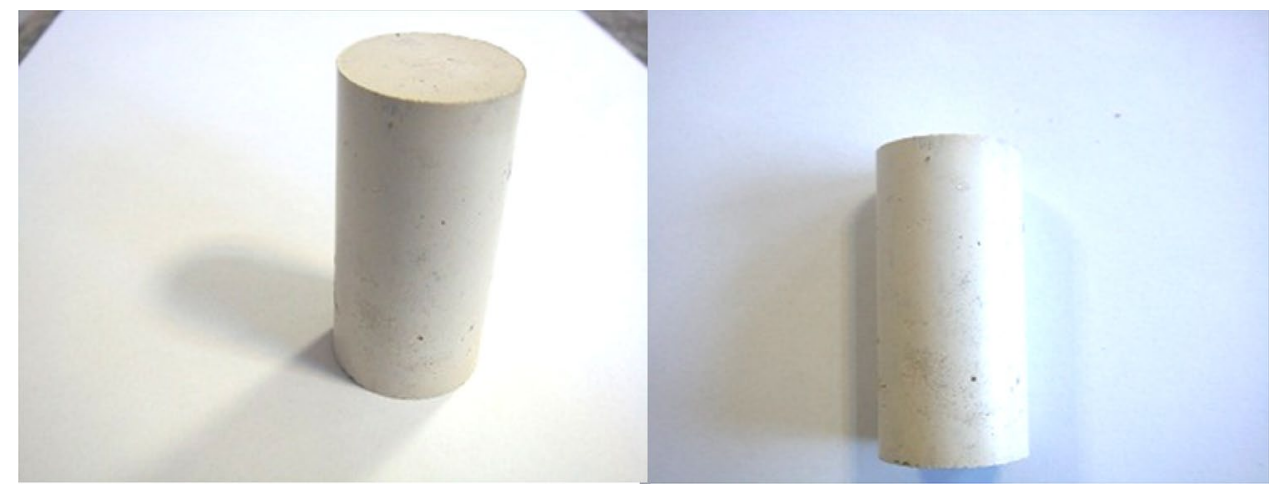

Table 5 Effect of metal oxides on artificial stone strength

\begin{tabular}{llllrr}
\hline Metal oxides & Color & Mineral additive (3\%) & $\begin{array}{l}\text { Compressive } \\
\text { strength (Mpa) }\end{array}$ & Tensile strength (Mpa) & Flexural strength (Mpa) \\
\hline- & Brown & Bentonite & $110.12 \pm 0.01$ & $41.35 \pm 0.01$ & $105.72 \pm 0.01$ \\
Titanium oxide & white & Bentonite & $108.23 \pm 0.01$ & $39.5 \pm 0.01$ & $103.42 \pm 0.01$ \\
$\begin{array}{l}\text { Titanium oxide and } \\
\text { copper oxide }\end{array}$ & Red & Bentonite & $106.97 \pm 0.01$ & $38.32 \pm 0.01$ & $101.26 \pm 0.01$ \\
\hline
\end{tabular}

\subsection{Acid resistance}

\subsubsection{Sulfuric acid test}

The sample with powder/resin ratio of $80 / 20$ along with bentonite additive has been used for acid test. First, artificial stone has weighted accurately, and then it is placed within a dilute acid (Sulfuric acid 10\%) for $24 \mathrm{~h}$. It makes an opportunity to investigate whether artificial stone is resistant enough against corrosion or not. Artificial stone has weighed after being dried. The difference between initial weight (before being placed in the dilute acid) and final weight (after being dried) indicates the degree of corrosion. The corrosion rate was $0.2 \% \pm 0.03$. It is less than corrosion in natural stones $(5 \%)$ in same condition. So, the results reveal that produced artificial stone is resistant enough against dilute acid. In other words, weight reduction is very low and the corrosion is ignorable.

\subsubsection{Hydrochloric acid test}

The same procedure has been done to assay the resistance of the produced artificial stone against another dilute acid (hydrochloric acid 10\%). The average corrosion rate for 10 samples was $0.65 \% \pm 0.03$. It is higher than the amount of corrosion in sulfuric acid test but lower than the corrosion in natural stones (7\%) in same condition. Considering the results, Hydrochloric acid causes more corrosion in the artificial stone than Sulfuric acid. So it is better to use this kind of artificial stones where it is less likely to contact with Hydrochloric acid.

\section{Conclusions}

In this research paper, artificial stone production using waste material from Alborz silica mineral processing factory has investigated to find the most optimum method of mass production. The maximum compressive strength of artificial stone (110 MPa) obtained in 80/20 powder/resin aggregate ratios, using 3\% bentonite at $90{ }^{\circ} \mathrm{C}$ while the strength has decreased slightly in other combination. Thus, bentonite increases the strength of the artificial stone without affecting the color and other characteristics. Besides, produced artificial stone has lower specific gravity $\left(2.14 \mathrm{~g} / \mathrm{cm}^{3}\right)$ and water absorption $(0.06 \mathrm{~g})$, which are prominent advantages of artificial stone. To have desired color, there are several metal oxides which can be added to the combination. The results showed that using metal oxides does not make a significant effect on artificial stone strength. Also, the corrosion rate using Sulfuric acid and Hydrochloric acid $(10 \%)$ is $0.2 \% \pm 0.03$ and $0.65 \% \pm 0.03$, respectively. It is less than corrosion amount in natural stones $(5 \%$ and $7 \%$ ) in same condition. Moreover, artificial stone production costs $30 \$$ per square meter, while natural quartz is $50 \$$ per square meter. So, this artificial stone has a good quality and can be used in civil construction. 
Acknowledgements The authors hereby would like to humbly appreciate the Mineral Processing department of Imam Khomeini International University for their technical collaboration and financial supports.

\section{Compliance with ethical standards}

Conflict of interest The authors declare that they have no conflict of interest.

\section{References}

1. Mannan UA, Islam MR, Tarefder RA (2015) Effects of recycled asphalt pavements on the fatigue life of asphalt under different strain levels and loading frequencies. Int J Fatigue 78:72-80. https://doi.org/10.1016/j.ijfatigue.2015.04.004

2. Norouzi S, Badii K, Ardejani FD (2010) Activated bauxite waste as an adsorbent for removal of acid blue 92 from aqueous solutions. Water Sci Technol 62:2491-2500. https://doi.org/10.2166/ wst.2010.514

3. Pasandín AR, Pérez I (2017) Fatigue performance of bituminous mixtures made with recycled concrete aggregates and waste tire rubber. Constr Build Mater 157:26-33. https://doi. org/10.1016/j.conbuildmat.2017.09.090

4. Gomes MLP, Carvalho EA, Sobrinho LN, Monteiro SN, Rodriguez RJ, Vieira CMF (2018) Production and characterization of a novel artificial stone using brick residue and quarry dust in epoxy matrix. J Mater Res Technol 7(4):492-498. https://doi. org/10.1016/j.jmrt.2018.08.012

5. Raposeiras AC, Vargas-Cerón A, Movilla-Quesada D, CastroFresno D (2016) Effect of copper slag addition on mechanical behaviour of asphalt mixes containing reclaimed asphalt pavement. Constr Build Mater 119:268-276. https://doi. org/10.1016/j.conbuildmat.2016.05.081

6. Rubio M, Moreno F, Belmonte A, Menéndez A (2010) Reuse of waste material from decorative quartz solid surfacing in the manufacture of hot bituminous mixes. Constr Build Mater. https ://doi.org/10.1016/j.conbuildmat.2009.09.004

7. Stefanidou M, Pachta V, Papayianni I (2017) Design and testing of artificial stone for the restoration of stone elements in monuments and historic buildings. Constr Build Mater 93:957-963. https://doi.org/10.1016/j.conbuildmat.2015.05.063

8. Uliana JG, Calmon JL, Vieira GL, Teixeira JESL, Nunes E (2015) Heat treatment of processing sludge of ornamental rocks: application as pozzolan in cement matrices. Ibracon Struct Mater J 8:100-123. https://doi.org/10.1590/S1983-41952015000200004

9. Carvalho EAS, Vilela NF, Monteiro SN, Vieira CMF, Silva LC (2018) Novel artificial ornamental stone developed with quarrywaste in epoxy composite. Mater Res 21:1-6. https://doi. org/10.1590/1980-5373-mr-2017-1104

10. Piazzarollo CB, Xavier GC, Alexandre J, Azevedo ARG, VieiraCMF MS (2016) Factorial design for experimental planning of clay ceramic incorporated with ornamental stone waste. Mater Sci Forum 869:127-130. https://doi.org/10.4028/www.scientific .net/MSF.869.127

11. Ribeiro CEG, Rodriguez RJS (2015) Influence of compaction pressure and particle content on thermal and mechanical behavior of artificial marbles with marble waste and unsaturated polyester. Mater Res 18:283-290. https://doi.org/10.1590/15161439.372314

12. Vieira CMF, Motta TS, Candido VS, Monteiro SN (2015) Addition of ornamental stone waste to improve distinct formulations ofclayey ceramics. Mater Sci Forum 820:419-424. https://doi. org/10.4028/www.scientific.net/MSF.820.419

13. Ribeiro CEG, Rodriguez RJS, Vieira CMF, Carvalho EAS, Candido VS, Monteiro SN (2014) Production of synthetic ornamental marble as a marble waste added polyester composite. Mater Sci Forum 445-776:341-345. https://doi.org/10.4028/www. scientific.net/MSF.775-776.341

14. Minnesota Pollution Control Agency (2016) Air monitoring at minnesota silica sand facilities, State of Minnesota. https ://www.pca.state.mn.us/air/air-monitoring-minnesota-silic a-sand-facilities. Accessed 2017

15. Arabani M, Azarhoosh AR (2012) The effect of recycled concrete aggregate and steel slag on the dynamic properties of asphalt mixtures. Constr Build Mater 35:1-7. https://doi. org/10.1016/j.conbuildmat.2012.02.036

16. Park SB, Lee BC, Kim JH (2004) Studies on mechanical properties of concrete containing waste glass aggregate. Cement Concr Res 34:2181-2189. https://doi.org/10.1016/j.cemco nres.2004.02.006

17. Pasandín AR, Pérez I (2015) Overview of bituminous mixtures made with recycled concrete aggregates. Constr Build Mater 74:151-161. https://doi.org/10.1016/j.conbuildmat.2014.10.035

18. Pasandín AR, Pérez I (2014) Mechanical properties of hot-mix asphalt made with recycled concrete aggregates coated with bitumen emulsion. Constr Build Mater 55:350-358. https://doi. org/10.1016/j.conbuildmat.2014.01.053

19. Wiemes L, Pawlowsky U, Mymrin V (2017) Incorporation of industrial wastes as raw materials in brick's formulation. J Clean Prod 142:69-77. https://doi.org/10.1016/j.jclepro.2016.06.174

20. Hou Z-Q, Gao Y-F, Qu X-M, Rui Z-Y, MO X-X (2004) Origin of adakitic intrusives generated during mid-Miocene east-west extension in southern Tibet. Earth Planet Sci Lett 220:139-155

21. Chang FC, Lee MY, Lo SL, Lin JD (2010) Artificial aggregate made from waste stone sludge and waste silt. J Environ Manag 91:2289-2294. https://doi.org/10.1016/j.jenvman.2010.06.011

22. Cruz J (2010) Process for manufacturing outdoor artificial stone boards with methacrylate resin by means of the vibro-compression under vacuum system. United States Patent Application 20100063193. Kind Code: A1

23. Lee MY, Ko CH (2008) Artificial stone slab production using waste glass, stone fragments and vacuum vibratory compaction. Cement Concrete Compos. https://doi.org/10.1016/j. cemconcomp.2008.03.004

24. Lee DJ, Shin IJ (2002) Effects of vacuum, mold temperature andcooling rate on mechanical properties of press consolidatedglass fiber/PET composites. Compos A 33:1107-1114. https://doi. org/10.1016/S1359-835X(02)00051-9

25. Ismail ZZ, Al-Hashmi EA (2009) Recycling of waste glass as a partial replacement for fine aggregate in concrete. Waste Manag 29(2):655-659. https://doi.org/10.1016/j.wasman.2008.08.012

26. Dos Santos JPL, Rosa LG, Amaral PM (2011) Temperature effects on mechanical behaviour of engineered stones. Constr Build Mater 25:171-174. https://doi.org/10.1016/j.conbuildma t.2010.06.042

27. Souza Silvaa F, Ribeirob CEG, Rodrigueza RJS (2018) Physical and mechanical characterization of artificial stone with marble calcite waste and epoxy resin. Mat Res. https://doi. org/10.1590/1980-5373-mr-2016-0377

28. Wang B, Li G, Han J, Zheng Y, Liu H, Song W (2017) Study on the properties of artificial flood-prevention stone made by Yellow River silt. Constr Build Mater 144:484-492. https://doi. org/10.1016/j.conbuildmat.2017.03.206

29. Peng L, Qin S (2018) Mechanical behaviour and microstructure of an artificial stone slab prepared using a $\mathrm{SiO}_{2}$ waste crucible and quartz sand. Constr Build Mater 171:273-280. https://doi. org/10.1016/j.conbuildmat.2018.03.141 
30. Alexandre J, Azevedo ARG, Xavier GC, Trindade JC, Botelho GK, Monteiro SN (2014) Addition of grog-clay ceramic waste in multiple use mortar. Mater Sci Forum 789-799:235-239. https://doi. org/10.4028/www.scientific.net/MSF.798-799.235

31. Candido VS, Pinheiro RM, Monteiro SN, Vieira CMF (2014) Microstructural analysis of clay ceramic added with argilliteand grog. Mater Sci Forum 789-799:219-223. https://doi.org/10.4028/ www.scientific.net/MSF.798-799.219

32. Grim RE (1978) Chapter 5 Properties and Uses of Bentonite. Dev Sedimentol 24:217-248. https://doi.org/10.1016/s0070 $-4571(08) 70615-0$

33. Miranda-Trevino JC, Coles CA (2003) Kaolinite properties, structure and influence of metal retention on $\mathrm{pH}$. Appl Clay Sci 23:133-139. https://doi.org/10.1016/s0169-1317(03)00095-4
34. Borselino C, Calbrese L, di Bella G (2009) Effects of powder concentration and type of resin on the performance of marble composite structures. Constr Build Mater 23:1915-1921. https://doi. org/10.1016/j.conbuildmat.2008.09.005

35. Carvalho EAS, Marques VR, Rodriguez RJS, Ribeiro CEG, Monteiro SN, Vieira CMF (2015) Development of epoxy matrix artificial stone incorporated with sintering residue from steel making industry. Mater Res 18:235-248. https://doi.org/10.1590/15161439.367514

Publisher's Note Springer Nature remains neutral with regard to jurisdictional claims in published maps and institutional affiliations. 